\title{
Urbs in Rure: Decorative Programmes and Architectural Models in Lusitania's Villae
}

\section{Kırsal Kentler: Lusitania Villaları'nda Dekoratif Programlar ve Mimari Modeller}

André CARNEIRO*

(Received 29 November 2016, accepted after revision 11 May 2017)

\begin{abstract}
One of the most remarkable characteristics in Lusitania's villae is their diversity: Each place embodies a set of contents and symbols, which were carefully defined by their owners. By analysing all the different architectural and iconographic variants, we are trying to understand who these domini were and how the elites conveyed all contents belonging to the bigger picture of the Mediterranean Oikoumene. Landscape, building spaces and plants, the relation between inner and outer environments, iconographic contents, and decorative grammar are analysed in order to be able to understand the way in which the cultural values found in Lusitania's villae were transmitted.
\end{abstract}

Keywords: Lusitania, Roman villa, decorative programs, Roman mosaics, Roman architecture.

\section{Öz}

Lusitania villarındaki en dikkat çekici özelliklerden biri onların çeșitliliğidir: Her yer, sahipleri tarafindan özenle tanımlanan içerikler ve sembollerden oluşmaktadır. Farklı mimari ve ikonografik değişkenleri analiz ederek, bu sahiplerin kim olduklarını ve bu seçkinlerin Akdeniz Oikoumene'sinin daha büyük resmine ait tüm içeriği nasıl aktardıklarını anlamaya çalışmaktayız. Lusitania villalarında bulunan kültürel değerlerin nasıl aktarıldı̆̆ını anlayabilmek için peyzaj, bina alanları ve bitkiler, iç ve dış çevre arasındaki ilişki, ikonografik ve dekoratif sembolik içerik incelenmiştir.

Anahtar Kelimeler: Lusitania, Roma villası, dekoratif program, Roma mozaikleri, Roma mimarisi.

\section{Previous words}

The term villa is one of the most used in archaeological bibliography. Out of curiosity, one can simply say that far too little is said about it on that time's epigraphy; however, many Latin authors have been using it either in 'technical' literature or in epistolary references and letters, where, in this case, they are written in the first person.

In order to get to know a villa, we are counting on two groups of authors. The first is a heterogeneous group of writers with the purpose of writing treaties with recommendations on the proper management of a farm business in common, which is why they are usually known as the Latin agronomists. In spite of the different times in which they have written, there is a common intent: an ideal farming business would have different components - residential (pars urbana), transformation, and storage rooms (pars rustica and/or pars fructuaria), which connect to the surrounding land (the fundus) -, for which the owner should follow a set of recommendations in order to profit from

\footnotetext{
* André Carneiro, Integrated Researcher at CHAIA-UÉ Research Collaborator at CECH-FLUC History Department at Universidade de Évora, Évora, Portugal.E-mail: ampc@uevora.pt
} 


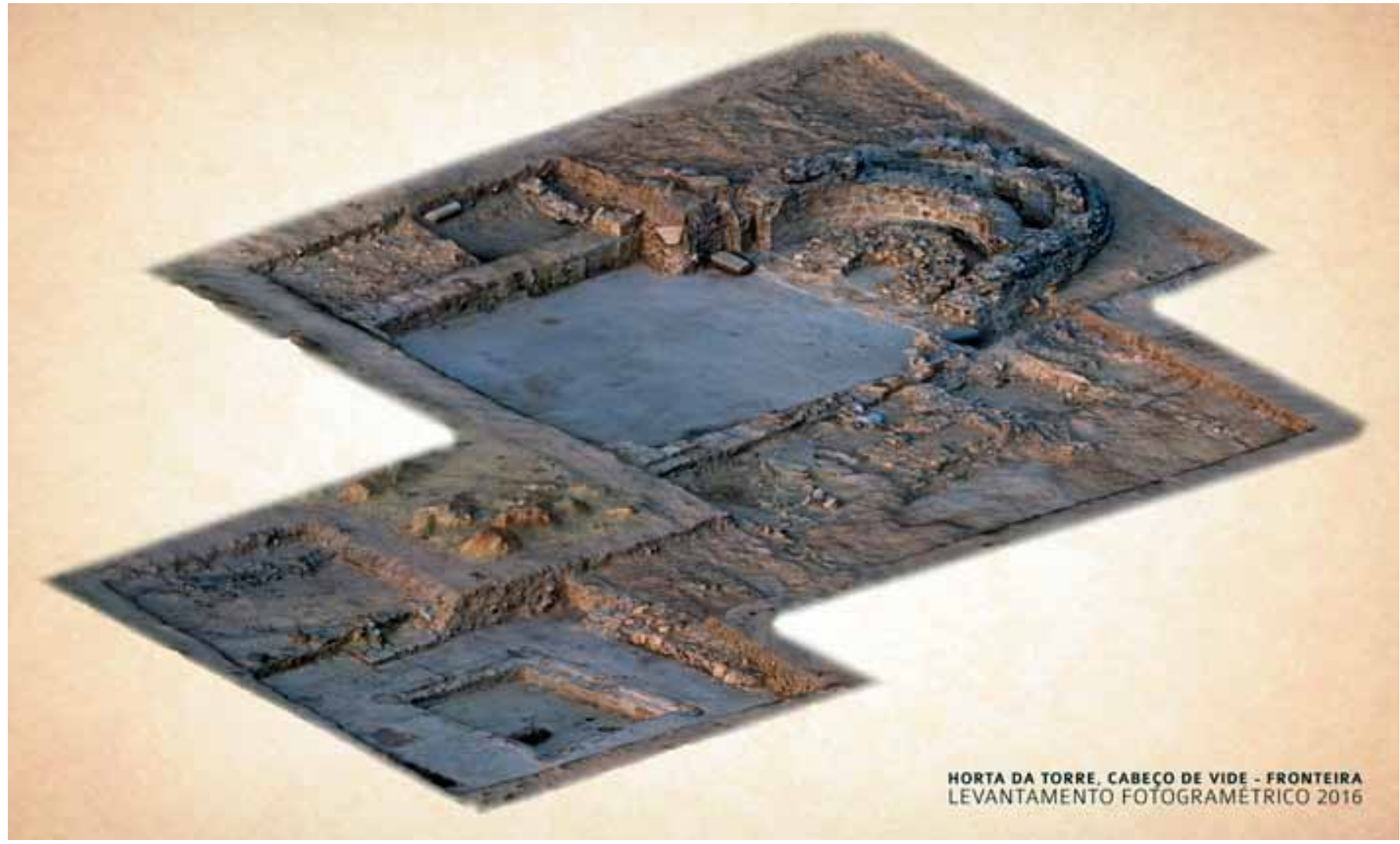

the whole lot. The villa is, therefore, a working space, which is understood as a whole group that ought to be profitable - so, it is a place for negotium. This layout and these purposes have remained for all the different authors, whatever the time in which they have written, and have formed a guideline with a background, as there were authors in Carthage who have written treaties on rural constructions ${ }^{1}$.

Another group of authors have also described their domains in accordance with a normally intimate speech that was found in epistolary correspondence and letters. This is a bigger batch, and chronologically more heterogeneous, as it runs from the $\mathrm{I}^{\text {st }}$ century BC (Cicero) to the $\mathrm{VI}^{\text {th }}$ century AD (Venantius Fortunatus). In this case, we are looking at scholars who live in second homes on a seasonal basis, and look for comfort, peace, and quiet in these countryside homes as opposed to the urban stress. Hence, the concept of rural life presented to us is essentially an idyllic and idealised one, for which the emphasis is on otium, the leisure time in which a person can enjoy reading, fruition, and writing (that is, otium litteratum).

Therefore, there is a big difference between these two blocks of authors: while the Agronomist treaty writers exalt the negotium, which is the productive component of the countryside, the scholars prefer the otium, which is the contemplative fruition that is also provided by the countryside. Does this mean that both groups complete each other and offer a balanced and objective vision of reality? No. This is not true for two reasons: first, both groups belong to the same social
Figure 1

Roman Villa in Horta da Torre (Fronteira). Orthophotogrammetry carried out at the end of the 2016 campaign by Carlos Carpetudo (CromelequeLda. http://www.cromeleque.com).

1 Although they have not reached us, there have been references (Columela, RR I, $1 ; 13 ; 18$ ) to works by an author named Mago, who would not have been the only Punic author. Pliny the Elder has reported (Plin.nat. 18, 22) that his treaty on agriculture was translated into Latin as determined by the Senate. One should also remember that Varro quoted almost fifty Greek authors, since there were also countless treaties on agriculture in Greece. 
reality. Both, treaty writers and scholars, are members of an urban and conservative elite, which does not live permanently in the countryside, but rather travel thereto for writing purposes. Secondly, both have built intentional speeches aiming at the creation of an archetype: in the first case, a described idealisation, where the villa is proposed; it is a space that does not really exist, but which may become a reality if recommendations are followed - for which they have been thoroughly described -, while in the case of the scholars, we have an idealised description, that is, places that really exist, but they have been described in accordance with rhetorical declarations common to all (and are often repeated ipsis verbis) where these descriptions only intend to emphasise an ideological speech. These letters do not comprise agricultural labour, the effort of work, or the hardships of life in the countryside; only times of leisure, reading, banquets, and welcoming guests. These are places that really exist, but they have been based on assumptions that mould their description and which intentionally seek to cause an emotional reaction in the reader.

This is why, if we analyse the texts written by the treaty writers and scholars, we will see repeats in each and every one of them, common narrations, literary formulas, and topoi. There are obviously specific elements and differences, but after a careful reading you will quickly identify common suggestions and solutions, or even sentences that almost repeat themselves. As, deep down, each group has a unique purpose, which has remained unchanged over history ${ }^{2}$.

\section{The beginnings, between the structuring of a new landscape and the productive paradigm}

Due to the historic process of the Roman conquest of Portugal, the most archaic examples of villae are not present, although there is evidence in other regions - such as the Hispanic case, where they feature more strongly in Catalonia. However, there are some relevant cases to be studied in Lusitania, separated into two essential groups.

First, there is the model of the republican farms, which are subjected to a broader discussion that goes far beyond this study ${ }^{3}$. Nevertheless, one should remember the experience of the outskirts of São Cucufate (Vidigueira), where field surveys have enabled us to identify a series of small farms, which, after several archaeological surveys, revealed short activity in the diachrony of occupation, that is, their abandonment two or three generations after their foundation. What reveals to be more interesting for the matter at hand are the dimensions of the involved structures: the case of Boa Vista, a small villa with a peristyle 'sans mosaique, sans stuc, sans marbre (...), des établissements modestes encore, mais de plan spécifiquement romain' (Mantas - Sillières 1990: 165) ${ }^{4}$, or Apariça, where the material collected contrasts with a 'ferme est bien exigue; c'est la forme la plus simple de la villa linéaire' (Mantas - Sillières 1990: 169) .

In the second case, we have the planimetric examples, which were fossilised in the whole plant, as there were no reconstructions or renovations eliminating these architectonic solutions. One of the most interesting cases is in Torre de

\footnotetext{
2 As I have discussed this subject recently, I shall refer interested readers to Carneiro 2014: 91-102, where you will be able to read a broader approach, or to more recent papers in print.

3 I am referring to the problem of south-west Castella and its functionality, among others. Please refer to Fabião 2002.

4 Refer to pl. LXXXVII

5 Refer to p. LXXXIX, C
} 
Palma (Monforte), where the pars urbana is being gradually extended into a magnificent example of the building's horizontal stratigraphy, since the atrium has remained even after the extensions, which were a result of the house with a peristyle and the room with a triple apse ${ }^{6}$. Another interesting situation is in the villa of Pisões (Beja), a residence where, after running through a long hallway filled with columns entering the building - possibly filled with gardens surrounded by trees -, you will find a staircase descending towards a perfectly Italian atrium. This space produces a small central impluvium decorated with four marble columns. This house still preserves over forty divisions, although none of them seems to indicate any monumentality, a particular ornamental apparatus, or in most cases, functionality ${ }^{7}$. That is, we have a relatively low profile and sober planimetry, which has survived the entire diachrony of occupation of this place (which is rare, as we know that owners tended to regularly carry out works and renovations on their properties).

Unfortunately, we do not have any more examples of occupied villae between the $\mathrm{I}^{\text {st }}$ and $\mathrm{II}^{\text {nd }}$ centuries of our Era, either due to later monumentalisation plans, which have erased all evidence of the first stages of the building - as is the case with Quinta das Longas, Elvas ${ }^{8}$-, or because archaeological research was not directed towards this purpose - recognising the models of occupation of the territory in the beginnings of Roman presence, between the end of the Republic and the Principality of Augustus 9 .

\section{The villa, between the otium and the voluptas}

From the late $1^{\text {st }}$ century $\mathrm{AD}$, we can see how each countryside residence came to transform into a place for socialising, which, throughout the Empire, became crucial in forging and cementing social bonds. The villa is a stage par excellence for interspersed feasts of theatre and poetry recitals, literary evenings, or coexisting to the sound of music. These are fundamental moments for strengthening friendship bonds and personal solidarity among aristocrats, and in order for this to be the best possible environment, these spaces had to be worked on. Rooms became gradually wider with better acoustics, filled with well-designed architectural solutions, which complement cultural contents intended to be shown. But it is also necessary to find creative elements, possibly somewhat spectacular, where one plays with their senses: the harmonious sound of running water, the false scenarios and trompe l'oeil, the play of colours, reflections and solutions for controlling light have been experimented up to their limit over the following centuries. This movement actually started in the Imperial Residences with Tiberius, Nero, and Hadrian, and their emulation and copy by private elites spread these solutions throughout the Empire.

At the same time, still in the early days of the Empire, the spreading of peristyle and breaking down spaces - which were more and more sectored and designed for specific purposes - allowed for residences to become more malleable from the point of view of architectonic design, where one would find original and

\footnotetext{
6 For example, refer to the plants in Lancha - André 2000.

7 In the absence of a comprehensive study on this place, or a synthesis monograph, one should continue to read the results by Ribeiro 1972. It is true that room 30 produces an apse and a central wide tank, but it has small dimensions and seems too eccentric in relation to the entrance atrium. This is often designated as a peristyle, but due to its dimensions and layout, it really is an atrium.

8 As an example, please refer to Carvalho - Almeida 2003, in relation to the differences between those designated as villa I and villa II.

${ }^{9}$ For examples and comments, see Terrenato 2007.
} 
highly creative solutions. They bear strong regional variations, which are proof of trends based on different prototypes: for example, while the clover-shaped room, or that with a triple apse, is common in the villae of Lusitania or Central Plateau, there is only one in a villa in Betica, in Fuentedueñas (Ecija).

In the same way, we could see another movement, which would come to its peak in the following centuries: the osmosis between indoor and outdoor areas. On one hand, the villa should be in harmony with the surrounding landscape, whether by choosing well where it would be implanted - the well-known search for ideal landscapes, either for the urbs or private houses -, or by domesticating all nature surrounding it (by creating terraces and thresholds; an artificial water mirror; or locations for contemplating the landscape). But on the other hand, experiencing this otium and convivium, which are essential for strengthening social bonds, may be possible by transposing the socialising spaces to the surrounding nature. Hence, we have the triclinium aestivalis structures - the small constructions that stand out in the main building -, where the dominus enjoys socialising with his guests, or where he goes to read or write. Pliny the Younger described these places many times, particularly his villa Laurentina, where he had a library and an apotheca, where he enjoyed greater privacy so that he could read and write. The Greek terms we employ, among many others, for each specific area of the house, show us how this entire movement was influenced by the Greek culture.

At the same time, other spaces have become more relevant as they perfectly adapt to the times of otium and convivium. I am particularly referring to the baths, as the small baths in Augustus' times were replaced with gradually elaborate and sumptuous spaces. The fruition of the baths became more relevant due to their inherent value - as a time to socialise, where you would have greater intimacy for conversations, but also to fulfil medical prescriptions which, particularly after Galen's treaties, recommended greater care in body treatments -, but they were also a complement to the feasting times ${ }^{10}$. Hence, baths became more relevant in regard to their planimetric design, and, since then, they became independent from the main building.

\section{Lusitania's villae: planning solutions, between the attachment to paradigms and the search for uniqueness}

There is a double tension in private residences throughout the Empire: on one hand, each possessor is attempting to show the way in which they master cultural archetypes in their architectural and decorative expression, that is, each residence should be fully incorporated into their time's cultural universe. However, there is an obvious temptation to the unicum, to show how each house comprises original and absolutely creative solutions, in order to create an unforgettable impact on each visitor.

This real explosion of creativity has resulted in unique solutions ${ }^{11}$, which combine the monumentality of outdoor spaces with the creation of artificial atmospheres,

10 Although there are unanswered questions in this passage, according to Satyricon (26.10) social groups would relax in a tepid bath in the middle of a feast while the room was being cleaned and prepared for the rest of the meal.

11 '(...) une varieté infinie des plans', as defined by Jean-Gérard Gorges (1979: 115), unlike the central European regions where we see more stereotypes, which also lead us to reflect on the way in which construction plans could be organised by architects. For further reflection on this process, please refer to the study by Gorges (2008) where he mentions 'strength and reflections in the rural world of a traditional and thriving Rome' (p. 46, own translation). 
the volumes that allow for wide indoor perspectives while contemplating the outdoors, and handling decorative programmes without any breaks on creation and aesthetic standards, which are curiously linked to traditional classic archetypes. This blossoming, unstoppable, and baroque architecture ${ }^{12}$ serves the ideals of the time's social and political values, such as the ars vivendi, which was organised around the otium litteratum, as well as the self-representation scenario of the dominus that implies the adventus and pompa processionalis, which are similar to the late antique imperial codes ${ }^{13}$. As it is evident, these single-power manifestations are more peacefully carried out in the peripheral places that are further away from the powerful quarters.

The visual relationship with the outdoors, according to the art of contemplation, which also expresses ownership - the peripheral view over a property reflects the power of the dominus, whether it is the factual view over the lands one can see, or the symbolic view over agricultural labourers -, is present in the case of São Cucufate (Vidigueira), where a cenatio room might also have existed filled with residually preserved mosaics (Alarcão - Étienne - Mayet 1990) ${ }^{14}$. Here in, the actual existence of a spacious gate that runs through the entire central façade serving as a wide visual point of contact with the outdoors reminds us of the countless representations of Tunisian mosaics, where the villae bear balconies with columns, which allow for a maximum fruition of this contemplatio. The triclinium associated with the 'octagonal belvedere', which was probably decorated with a sculptural cycle, in the room where a bump on the floor highlights the 'majésté du lieu', illustrates the way in which these outdoor/indoor visual relations are manipulated, and how imperial prototypes and codes are particularly reflected according to the façade's external monumentality.

Indoor spaces are also filled with solutions, which continue this duality between the landscape and the structure that was built, hence creating artificial environments filled with allegories and cultural content. The use of water as an element, which creates a grand scene, is not surprising in Lusitania, where one can see these prototypes being adopted. We know two rural examples of stibadia within the pars urbana framework. In the case of the Rabaçal villa (Pessoa 2008), we stand before a moving structure, which, similarly to many others in Hispania, masters a triclinium that comprises the room with a triple apse. The floor was made with polychrome mosaics, which contain the most relevant figures in the entire villa, although the two side apses bear opus signinum. The existence of five water supply channels below the mosaic covering the central apse had the central area regularly flooded with water ${ }^{15}$.

Another example is in the Roman villa of Horta da Torre (Fig. 1), which has been undergoing excavation works by the signatory since $2012^{16}$. In this case, we have a stibadium built with blocks of stone coated with stucco, which can be found in the centre of an apse that stands out in a quadrangular room, which has not been entirely excavated, but should amount to a total surface of about $90 \mathrm{~m}^{2}$. This room has been entirely covered in opus signinum, a solution that serves as

\footnotetext{
12 For a well-known example, see Gallochio 2014.

13 In order to be fully in line with these meanings, the work of Sabine MacCormack (1981) remains essential.

14 cap. V - L'étage noble (p. 121-126).

15 The author introduces two interpretations, where one points towards the existence of 'five resonant cavities' (Pessoa 2008: 151) during musical events, since he does not identify a water drainage system which according to the first interpretation would fill the triclinium space.

16 Research Project FRONTAGER as approved by IGESPAR, and later on, DGPC, with the exclusive logistical and financial support of Fronteira Municipality.
} 
perfect waterproof for the floor, except for a small step, which highlights the apse, with great greyish-white marble slabs outlining it. The water was supplied through quadrangular holes covered in tiles, which allowed for water to pour from the wall behind the stibadium, hence forming artificial waterfalls pouring from a hidden tank inside the apse's wall. Thus, the social groups would dine reclining on the stibadium with a wall behind them, from which water would be falling and spreading freely all around a great quadrangular room, in the end of which one would see a drainage point. The solution that was found is extremely spectacular and unequivocally parallel to the triclinium of the villa in Faragola (Volpe 2006) or El Ruedo (Cordoba) (Vaquerizo Gil - Noguera Celdrán 1997), as well as other places with a stibadium, thus marking an indispensable role which this element took on in the new socialising ways of Late Antiquity (Morvillez 1996). In refined and representative contexts, water takes on a fundamental role in creating scenarios, which lead to the necessary amoenitas for a region with hot summers; however, reflections, the play of colours, or even the relaxing sound of fountains and waterfalls also contribute towards reinforcing the intended environment. The best example in Portugal for the use of this resource in a rural environment is the well-known nymphaeum in the villa of Quinta das Longas (Elvas) (Carvalho - Almeida 2003), where water combined with the two-colour opus sectile floor and the sculpture repertoire, certainly created an impressive atmosphere. Thus, this otium et contemplatio ideal was met, with an environment leading to intellectual gratification in socialising, of which authors have left us with plenty of literary descriptions. The spaces built, into which nature is transported, combined with the outdoor landscape, which serves as a frame and complement, are quite evident in Quinta das Longas, where the nymphaeum is elevated over the riverside of Ribeira de Chaves, 'where the water takes on a "scenic" role in this architectural construction as a whole' (Carvalho - Almeida 2003: 117; Rodríguez - Carvalho 2008: 311-318).

This means that the purpose of the dominus is the search for a harmonious ideal in the fusion between the human world and natural or cosmic order. It is thus no surprise that Orpheus - the mythical figure that embodies this meeting between what is human and what is natural - has had so many representations according to a pantheistic view that focuses on the dominus, the real kosmokrator of the surrounding environment. Orpheus symbolises this harmony between the human sphere and nature, therefore it is significant for us to find such depictions in mosaics that focus on two regional areas: around Augusta Emerita (Alvarez Martinez - Nogales Basarrate 1994) (El Pesquero and La Atalaya) and Colipo (Arneiro, or Arnal, and Martim Gil). This aspiration was typical at a time of high spirituality, where the villae owners conceived a considerably symbolic domain: their property was no longer a mere productive space for negotium, to become the place to celebrate the osmosis between the human order and natural planning in search of full harmony, which is symbolised by Orpheus. We can see this search in other elements: for example, the celebration of life is expressed by the appearance of Bacchus, who is often represented in mosaics, where the Dionysian thiasos appears at the same time as the adventus celebrating the arrival of the dominus. These mosaic representations of Bacchus surrounding Augusta Emerita were also emphasised (Alvarez Martinez - Nogales Basarrate 1994), as was the case with the villae at El Hinojal or La Cocosa; however, the most symbolic regional case was certainly the set in Torre de Palma (Monforte). In addition to the mosaic representing the triumph of Bacchus in detail, there is a subtle series of inter-textual relationships, which I have highlighted in another place (Carneiro 2014: 343-344 vol. II), where the designation of each horse 
depicted on the main panel of the room with a triple apse also takes us to the different stages of the Dionysian cycle, and also reflect the owner's possession of the most subtle cultural loads, which are inherent to the Greek world view. Therefore, in this scenario, the existence of a panel that depicts the muses in the same archaeological space is perfectly natural, since it shows the owner's profound cultural ecumenism, which he also expected his social group to recognise and share.

\section{Bibliography - Kaynaklar}

Alarcão - Étienne - Mayet 1990

J. de Alarcão - R. Étienne - F. Mayet, Les villas romaines de São Cucufate (Portugal), Paris, E. de Boccard.

Álvarez Martínez - Nogales Basarrate 1990

T. Álvarez Martínez - J. M. Nogales Basarrate, “Algunas consideraciones sobre la decoración de las villae del territorium emeritense: musivaria y escultura", J.-G. Gorgeset - M. Salinas de Frías (eds.), Les campagnes de lusitanie romaine: occupation du sol et habitats. (Collection de la Casa de Velázquez n. 47) Madrid/ Salamanca, Casa de Velázquez/Ediciones Universidad de Salamanca, 273-296.

Carneiro 2014

A. Carneiro, Lugares, tempos e pessoas. Povoamento rural romano no Alto Alentejo. Coimbra, Imprensa da Universidade de Coimbra, colecção Humanitas Supplementum n. 30.

Carvalho - Almeida 2003

A. Carvalho - M. J. de Almeida, “A água e o mármore na villa baixo-imperial da Quinta das Longas (S. Vicente e Ventosa, Elvas), Elvas-Caia”, Revista Internacional de Cultura e Ciência, 113-126.

Carlos 2002

F. Carlos, "Os chamados castella do sudoeste: arquitectura, cronologia e funções”, Anejos España Antigua 75, 177-193.

Gallochio 2014

E. Gallochio, "Aule tardoaniche a pianta basilicale: consoderazioni architettoniche e decorative a partire dall'esempio della Villa del Casale", P. Pensabene - C. Sfameni (eds.), La Villa Restaurata e i Nuovi Studi sull'Edilizia Residenziale Tardoantica, Bari, Edipugla, 277-287.

Gorges 1979

Gorges 2008

J. G. Gorges, Les Villas Hispano-Romaines: inventaire et problématique archéologiques, Paris, E. de Boccard.

J. G. Gorges, "L'architecture des villae romaines tardives: la création et le développement du modèle tétrarchique", C. Fernández Ochoa - V. García-Entero - F. Gil Sendino (eds.), Las villae tardorromanas en el occidente del Imperio. Arquitectura y función. IV Coloquio Internacional de Arqueología en Gijón, Gijón, Ediciones Trea, 27-48.

Lancha - André 2000

J. Lancha - P. André, Corpus dos mosaicos romanos de Portugal. II - Conventvs Pacensis. 1 - A villa de Torre de Palma, 2 volumes, Lisbon, Instituto Português de Museus.

MacCormack 1981

S. MacCormack, Art and ceremony in Late Antiquity. Berkeley, University of California Press.

Mantas - Silliéres 1990

V. G. Mantas - P. Silliéres, "La vie économique du domaine et des villas", J. de Alarcão- R. Étienne - F. Mayet, Les villas romaines de São Cucufate (Portugal), Paris, E. de Boccard, 149-186.

Morvillez 1996

E. Morvillez, "Sur les installations de lits de repas en sigma dans l'architecture du Haut et du Bas- Empire", Pallas 44, 119-138.

Pessoa 2008

M. Pessoa, "Um stibadium com mosaico na villa romana do Rabaçal”, Revista de Historia da Arte 6, 139-161.

Ribeiro 1972

F. N. Ribeiro, A villa romana de Pisões, Beja.

Rodríguez - Carvalho 2008 M.F.G. Rodríguez - A. Carvalho, "Torre Águila y las villas de la Lusitania interior hasta el occidente atlántico", C. Fernández Ochoa - V. García Entero - F. Gil Sendino (eds.), Las villae tardorromanas en el occidente del imperio: Arquitectura y Función, IV Coloquio Internacional de Arqueologia en Gijón, Ed. Trea, Gijón, Ed. Trea, 302-344.

Terrenato 2007 N. Terrenato, "The essential countryside. The Roman world" S. Alcock - R. Osborne (eds.) Classical Archaeology, London, Blackwell, 144-167.

Vaquerizo Gil - Noguera Celdrán 1997

D. Vaquerizo Gil - J.M. Noguera Celdrán, La villa romana de El Ruedo (Almedinilla, Cordoba). Decoración escultórica y interpretación, Murcia.

Volpe 2006

G. Volpe, "Stibadium e convivium in una villa tardoantica (Faragola - Ascoli Satriano)" M. Silvestrini T. Spagnoulo Vigorita - G. Volpe, (eds.), Studi in onore di Francesco Grelle, Bari, 319-349. 